\title{
The Role of PPATK in Proving Money Laundering Crimes
}

\author{
Adhar $^{*}$, Amiruddin $^{* *}$, L. Sabardi** \\ * Student of Magister Law Study Program, Postgraduate Program, Mataram University, Indonesia \\ ** Lecture of Law Faculty Mataram University, Indonesia
}

\begin{abstract}
The research aims to find out the PPATK's Duties and Authorities in Law 8 of 2010 concerning Prevention and Eradication of Crime of Money Laundering and the Role of the PPATK in Proving Money Laundering Crimes.

Duties and Authorities of PPATK in Law 8 of 2010 concerning Prevention and Eradication of Money Laundering Crimes. The aim of the PPATK is to Prevent and Eradicate Money Laundering Crimes, thus giving birth to an authority, namely 1). Collect, conclude, collect, analyze, evaluate information obtained from financial service providers, make guidelines on procedures for reporting suspicious financial transactions, 2). Provide advice and assistance to other authorized agencies regarding information obtained in accordance with the provisions of the Act on Money Laundering, 3). Provide recommendations to the government regarding the prevention and eradication of criminal acts of money laundering, 4). Report the results of analysis of financial transactions that indicate criminal acts of money laundering to the police for the purposes of investigation and prosecution for the purposes of prosecution and supervision, and 5). Make and submit reports on the analysis of financial transactions and other activities periodically to the President, Parliament, and institutions authorized to supervise Financial Service Providers (PJK). The role of PPATK in Proof of Money Laundering is PPATK in eradicating criminal acts of money laundering if it finds indications of suspicious transactions, cash transactions over five hundred million rupiahs, or transfers from and or abroad PPATK submits the results of investigations to investigators for investigation. In this case the PPATK only conducts the final assessment of the entire process of problem identification, analysis, evaluation of suspicious financial transactions conducted independently, objectively and professionally. However, the role of PPATK is very decisive in the process of identifying money from original crimes as evidence for investigators in proving the crime of money laundering.
\end{abstract}

Keywords: the role of PPATK, proof, money laundering

\section{Introduction}

This money laundering problem has received international attention because of its dimensions and implications which violate national boundaries. As a phenomenon of a crime called "organized crime", it turns out that there are certain parties who take advantage of money laundering traffic without realizing the impact losses incurred. Relating to this last thing is the world of banking, which on the one hand operates on the basis of the trust of consumers and on the other hand can be used as a means to let money laundering crimes. ${ }^{1}$ Speaking of money laundering crimes applied in Indonesia, it is certainly not possible without understanding the philosophical and for what purpose the anti-money laundering provisions were born. Anti money laundering is not born out of the spirit of just a few countries but arises at the initiative of various countries through the birth of an international convention. ${ }^{2}$

\footnotetext{
${ }^{1}$ Ilman Mujaddid, Kebijakan Hukum Pidana Dalam Pemberantasan Tindak Pidana Pencucian Uang, (Journal), Jurnal IUS, Vol IV, Nomor 1, April 2016.

${ }^{2}$ Yenti Garnasih, Penegakan Hukum Anti Pencucian Uang dan Permasalahannya di Indonesia, $3^{\text {th }}$ print, Rajagrafindo Persada, Jakarta, 2016, p. 12
} 
The new paradigm that was built in the recording of crimes by promoting follow the suspect and following the money not only arrested the perpetrators and processed the cases, but also traced the flow of funds and the location of the existence of assets or assets and then seized for the State. ${ }^{3}$

One of the key factors to eradicate money laundering is the need for a special body to handle illegal efforts in the practice of money laundering. This body is important because the problems of money laundering crimes are quite heavy, complicated, and trans-scale scale that is through the boundaries of state jurisdiction or are transnational and international. ${ }^{4}$ Internationally formed FIU is an institution born to eradicate criminal acts of money laundering and terrorism funding.

In this framework, the Money Laundering Law established a special body for money laundering called the Financial Transaction Reports and Analysis Center (PPATK), which is an independent institution that is directly responsible to the President. The establishment of the PPATK aims to prevent and eradicate money laundering. As an effort of Indonesia as a country that supports the anti-money laundering regime.

In the construction of the anti-money laundering regime in Indonesia, PPATK is placed as a focal point, which has a financial intelligence function to law enforcement officials about alleged money laundering or suspected origin of criminal acts. ${ }^{5}$

Law Number 15 of 2002 concerning Money Laundering Crime expressly mandates the establishment of the Financial Transaction Reports and Analysis Center (PPATK). Then amended by Law Number 8 of 2010 concerning Prevention and Eradication of Money Laundering Crimes, by increasing the authority of PPATK.

PPATK seems to be passive, which is limited to requesting or collecting reports to financial service providers, namely to bank financial institutions and non-bank financial institutions, then analyzing the results that have been analyzed to the police and prosecutors. ${ }^{6}$ However, in 39 Law Number 8 of 2010 concerning Prevention and Eradication of Money Laundering Crimes, PPATK has the task of preventing and eradicating money laundering.

The provisions contained in Article 39 of Law Number 8 of 2010 concerning Prevention and Eradication of Money Laundering Crime, namely the provisions concerning the duties of the PPATK, namely Preventing the occurrence of criminal acts of Money Laundering and Eradicating the occurrence of Money Laundering. Judging from its duties, the PPATK has a role in eradicating money laundering. Therefore, the PPATK can play a role in proving the crime of money laundering. However, in order to carry out this task there was a vagueness of norms related to the authority of the PPATK in proving criminal acts of money laundering, because it was not explained in a limited manner regarding the authority in eradicating money laundering.

Based on this background, the main problem can be drawn, namely 1) PPATK's Duties and Authorities in Law 8 of 2010 concerning Prevention and Eradication of Money Laundering Crimes; 2) The Role of the PPATK in Proving Money Laundering Crimes.

\section{Research Method}

This type of research is normative legal research. Normative research is that the law is often conceptualized as what is written in law in books or the law is conceptualized as a rule or norm which is a benchmark of human behavior that is deemed appropriate. ${ }^{7}$ Normative legal research is research that has the object of rule and rule of law. ${ }^{8}$ Normative legal research aims to find a clear legal basis in putting the issue of legal perspective. The method of approach used in this study are:

\footnotetext{
${ }^{3}$ Muhammad Yusuf, Kapita Selekta TPPU: Kumpulan Pembahasan Mengenai Isu-Isu Terkini, $2^{\text {th }}$ print, Pusat Pelaporan dan Analisis Transaksi Keuangan (PPATK), Jakarta, 2016.

${ }^{4}$ Christian Sondakh, Kewenangan PPATK dalam Menanggulangi Tindak Pidana Pencucian Uang Menurut Undang-Undang No. 8 Tahun 2010, (Jurnal), Lex Crimen Vol. IV/No. 8/Oct/2015152.

${ }^{5}$ Muhammad Yusuf, Kapita Selekta TPPU: Kumpulan Pembahasan Mengenai Isu-Isu Terkini, $2^{\text {th }}$ print, Pusat Pelaporan dan Analisis Transaksi Keuangan (PPATK), Jakarta, 2016, hlm.

${ }^{6}$ Amelia Fransisca Wattie, Peran PPATK Dalam Penyidikan Tindak Pidana Pencucian Uang, (Jurnal), Lex Crimen Vol. IV/No. 3/May/2015, p. 128

${ }^{7}$ Amiruddin dan ZainalAsikin, Pengantar Metode Penelitian Hukum, Print VII, PT Raja Grafindo Persada, Jakarta, 2006, p. 118.

${ }^{8}$ Mukti Fazar ND dan Yulianto Achmad, Dualisme Penelitian Hukum Normatif dan Empiris, Print IV, Pustaka Pelajar, Jakarta, 2017, p. 36
} 
a. The Statute Approach, regulatory approach is an approach using legislative and regulation. ${ }^{9}$ Ratio legislation and the ontological basis of a law to confirm the philosophical content contained in the law, so that it can be concluded whether there is a philosophical clash in the law. Such as Law Number 8 of 2010 concerning Prevention and Eradication of Money Laundering and Regulations concerning PPATK.

b. Historical approach (historical approach) is a historical approach bent in the framework of tracking the history of legal institutions from time to time. This approach is very helpful for researchers to understand philosophical rules from time to time. ${ }^{10}$ As in the plan, this study looks back at the history of the formation of the PPATK and the establishment of the Law on the crime of money laundering from time to time.

c. Conceptual Approach, that is, the approach taken by the reviewer of the literature that has to do with the problems to be studied. Such as books, journals, theses, desertions and other scientific works.

In this study the legal materials used consist of legal material in the form of:

a. Primary Law Material

Primary legal material is legal material that has binding legal force consisting of:

1) Law Number 30 of 2014 concerning Government Administration.

2) Law Number 8 of 2010 concerning Prevention and Eradication of Money Laundering Crimes.

3) Presidential Regulation of the Republic of Indonesia Number 50 of 2011 concerning Procedures for Implementing the Authority of the Financial Transaction Reports and Analysis Center (PPATK).

b. Secondary Legal Material

Secondary legal materials, namely legal materials that describe primary legal material, namely in the form of literature books, scientific works to look for concepts, opinion theory that is closely related to the problems studied.

c. Tertiary Legal Materials

Tertiary Legal Materials are materials that provide instructions and explanations for primary and secondary legal materials such as Legal Dictionary, Encyclopaedia, and so on.

Legal Material Collection Techniques, namely library legal materials, namely collection of legal materials with library studies of legal materials, batik primary legal materials, secondary legal materials, or tertiary legal materials and or non-legal materials. Search for legal material by reading, seeing, listening and through internet media. ${ }^{11}$ By way of collecting and reviewing library legal materials consisting of legislation, namely Law Number 8 of 2010 concerning Eradication and Prevention of Money Laundering, and Regulations concerning PPATK.

Legal Material Analysis is a legal material that is systematically then analyzed using interpretation. Interpretations used in this writing by using legal interpretation are: ${ }^{12}$

a. Systematic interpretation if a term or word is included more than once in an article or law, then the understanding must be the same. So that in this study the concept of money laundering in Article 2 must be the same as the concept of money laundering in the next article such as Law Number 8 of 2010 concerning Eradication and Prevention of Money Laundering.

b. Teleological interpretation is to find the purpose and purpose of a law. In this research proposal the purpose and purpose of the PPATK formation in Law Number 8 of 2010 concerning Eradication and Prevention of Money Laundering.

c. Authentic interpretations are interpretations given by legislators as attached to the law as explanations. In this paper looking back at the authority of PPATK in Law Number 8 of 2010 concerning Eradication and Prevention of Money Laundering.

By using these interpretations to build legal arguments or better known as legal constructions as a fact, it is deductively arranged to conclude from the general thing to the specific thing.

\section{Result And Discussion}

\footnotetext{
${ }^{9}$ Peter Mahmud Marzuki, Penelitian Hukum, Print XII, Kencana, Jakarta, 2016, p. 137

${ }^{10}$ Peter Mahmud Marzuki, Op.Cit, p. 166

${ }^{11}$ Mukti Fazar ND dan Yulianto Achmad, Op.Cit, p. 160

${ }^{12}$ Amirudin dan Zainal Asikin, Op.Cit, p. 165-166
} 


\subsection{Duties and Authority of the PPATK in Law 8 of 2010 concerning Prevention and Eradication of Money Laundering Crimes}

Basically, the PPATK's task as the Financial Intelligence Unit does not view the perpetrators as bureaucrats, technocrats, and executive or judicial legislatures, let alone assess morality or reported parties.

The source of authority of the PPATK is attributive authority ${ }^{13}$, namely the authority granted by law to government agencies and / or officials. The law that gives authority is Law Number 8 of 2010 concerning Prevention and Eradication of Money Laundering Crimes. For changes to Law Number 25 of 2002 concerning Money Laundering Crimes. The existence of the PPATK institution to combat organized transnational crime such as terrorism, narcotics awareness and money laundering. However, it is more emphasized in Law Number 8 of 2010 concerning Prevention and Eradication of Money Laundering Crime, namely as the Financial Transaction Analysis and Transaction Center as the official name of PPATK.

The task of the PPATK is to prevent and eradicate money laundering. In carrying out its duties as referred to in Article 40, PPATK has the following functions:

a. Prevention and eradication of money laundering crimes;

b. Management of information data obtained by PPATK;

c. Supervision of compliance of the reporting party; and

d. Analysis or examination of reports and information on financial transactions that indicate criminal acts of money laundering and / or other criminal acts as referred to in Article 2 paragraph (1).

The authority of the PPATK has to prevent and eradicate money laundering: ${ }^{14}$

a) Collect, conclude, collect, analyze, evaluate information obtained from financial service providers.

b) Make guidelines on procedures for reporting suspicious financial transactions.

c) Provide advice and assistance to other authorized institutions regarding information obtained in accordance with the provisions of the Act on money laundering.

d) Provide recommendations to the government regarding the prevention and eradication of money laundering.

e) Report the results of analysis of financial transactions that indicate money laundering crimes to the police for the purposes of investigation and prosecution for the purposes of prosecution and supervision.

f) Make and submit reports on the analysis of financial transactions and other activities periodically to the President, Parliament, and institutions authorized to supervise Financial Service Providers (PJK).

The authority possessed by the PPATK is the rights owned by the Agency and / or Government Officials or other state administrators to make decisions and / or actions in the administration of government. In this case the PPATK has the right to prevent and eradicate money laundering.

In the law enforcement process, PPATK can collaborate and assist investigators and prosecutors with the information they have and their analytical skills. This information can come from the PPATK data base or it can also come from sharing information with FIU from other countries. ${ }^{15}$

"In carrying out its duties and authorities, PPATK certainly requires coordination and cooperation with state institutions and other law enforcement agencies, including the issue of money laundering in the banking sector which is so vulnerable to money laundering. With this, cooperation and coordination with oversight institutions must be further enhanced so that it will provide performance effectiveness for PPATK whether it is able to overcome the problem of money laundering in Indonesia. Moreover, with the various modes nowadays, PPATK is demanded as a leading role that is able to become the axis of cooperation in preventing money laundering in banking with financial and banking institutions and law enforcement."16

\footnotetext{
${ }^{13}$ See Article 1 number 22 of Law Number 30 of 2014 concerning Government Administration which explains the source of authority Attribution is the granting of authority to the Agency and / or Government Officials by the 1945 Constitution of the Republic of Indonesia or the Law.

${ }^{14}$ Ibid, p. 86-87

${ }^{15}$ Johari, Tugas Dan Wewenang Pusat Pelaporan dan Analisis Transaksi Keuangan (PPATK) Dalam Pemberantasan Tindak Pidana Pencucian Uang, (Jurnal) Fiat Justisia Jurnal Ilmu Hukum Volume 5 No.3, September-December 2011. p. 386

${ }^{16}$ Rido Tri Sandi Rambe, Peranan Pusat Pelaporan Analisis Transaksi Keuangan (PPATK) Dalam Mencegah Tindak Pidana Pencucian Uang Dengan Modus Private Banking Berdasarkan Undang-Undang Nomor 8 Tahun 2010 Tentang Pencegahan Dan Pemberantasan Tindak Pidana Pencucian Uang, (Jurnal), JOM Fakultas Hukum Volume III Number 1 February 2016 , p. 3-4.
} 
Cooperation in the prevention and eradication of the crime of money laundering is regulated in Article 88 to 89 of the Republic of Indonesia Law No. 8 of 2010 concerning Prevention and Eradication of Money Laundering Crimes, namely:

a. National cooperation carried out by PPATK with related parties is set forth with or without form of formal cooperation.

b. International cooperation is carried out by PPATK with international institutions related to the prevention and eradication of acts of money laundering.

c. International cooperation carried out by PPATK can be carried out in the form of formal cooperation or based on mutual assistance or the principle of reciprocity.

According to Pathorany Halim, the handling of criminal acts of money laundering is a heavy duty of the PPATK, especially to detect the occurrence of criminal acts of money laundering and further criminal acts. So that prevention and eradication of money laundering requires a systematic and comprehensive mechanism that includes the process of detection and legal process. ${ }^{17}$

In reality, the practice of crime of money laundering is through a banking mechanism. Banks are the most vulnerable financial institutions or institutions that are often used or become the target of money laundering practices. Because banking is an institution favored by money launderers, among others, because it has a filtering system of international correspondence with the existence of a bank secret system. The role of the financial industry in preventing and combating money laundering can be said to be very prominent. Banking and other financial service providers are the spearhead (Front Line) in the anti money laundering regime. Financial institutions together with their employees are at the forefront of efforts to combat illegal financial activities. $^{18}$

The formation of the PPATK is an important step in the effort to combat money laundering in Indonesia. but to make the functions and duties more effective, the PPATK must also be given the authority to carry out because the nature of the establishment of this institution is to carry out prevention and control so that efforts to prevent and overcome the authority to conduct investigations are a very important element and should be attached to PPATK. ${ }^{19}$

The relationship between PPATK and the reporting party of Law Number 8 of 2010 concerning Prevention and Eradication of Money Laundering Crimes requires the reporting party (PJK) to submit three types of reports to PPATK, namely Suspicious Financial Transaction Reports (LTKM), Cash (LTT) Financial Transaction Reports and international financial transfer transaction (International Fund Transfer Instruction). ${ }^{20}$ The authority of the PPATK in receiving reports from financial services and goods or services procurement institutions is mandatory, administrative sanctions will not be implemented.

\subsection{The role of the PPATK in Proving Money Laundering Crimes}

Certainty is a feature that cannot be separated from the law, especially for written legal norms. Law without the value of certainty will lose meaning because it can no longer be used as a guideline for everyone. Certainty itself is referred to as one of the objectives of the law. Therefore, the PPATK in carrying out the authority to carry out prevention must be based on the law.

The authority of the Financial Transaction Reports and Analysis Center is that there are Functions, Tasks and Authorities of PPATK in following up when there are reports from law enforcement officials in this matter the Police, Prosecutors, and KPK can act to prevent transactions in individuals or corporations during or after the legal process of the original criminal offense is underway by analyzing the data submitted in relation to indications of money laundering.

\footnotetext{
${ }^{17}$ Christian Sondakh, Op.Cit, p. 156

${ }^{18}$ Ibid,.

${ }^{19}$ Ibid, p. 158

${ }^{20}$ Khairul, Mahmul Siregar, Marlina, Kewenangan PPATK Dalam Pencegahan Dan Pemberantasan Tindak Pidana Pencucian Uang, (Jurnal) Mercatoria Vol. 4 No. 1 Tahun 2011, p. 41
} 
To support the PPATK's authority in preventing money laundering crimes, it can also carry out cooperation in exchanging information with parties, both nationally and internationally, including: ${ }^{21}$

a. Law enforcement agencies;

b. Institutions authorized to supervise financial service providers;

c. Institution in charge of examining the management and responsibility of state finances;

d. Other institutions related to the prevention and eradication of money laundering crimes;

e. Financial intelligence units of other countries.

In conducting cooperation PPATK has an important role as a liaison institution between law enforcement agencies and other institutions as described above, because the role of PPATK has the authority to carry out analysis of cash financial transactions, suspicious, and funds from and to foreign countries, then the results the analysis or the results of the examination are only submitted by the institution authorized to carry out the investigation.

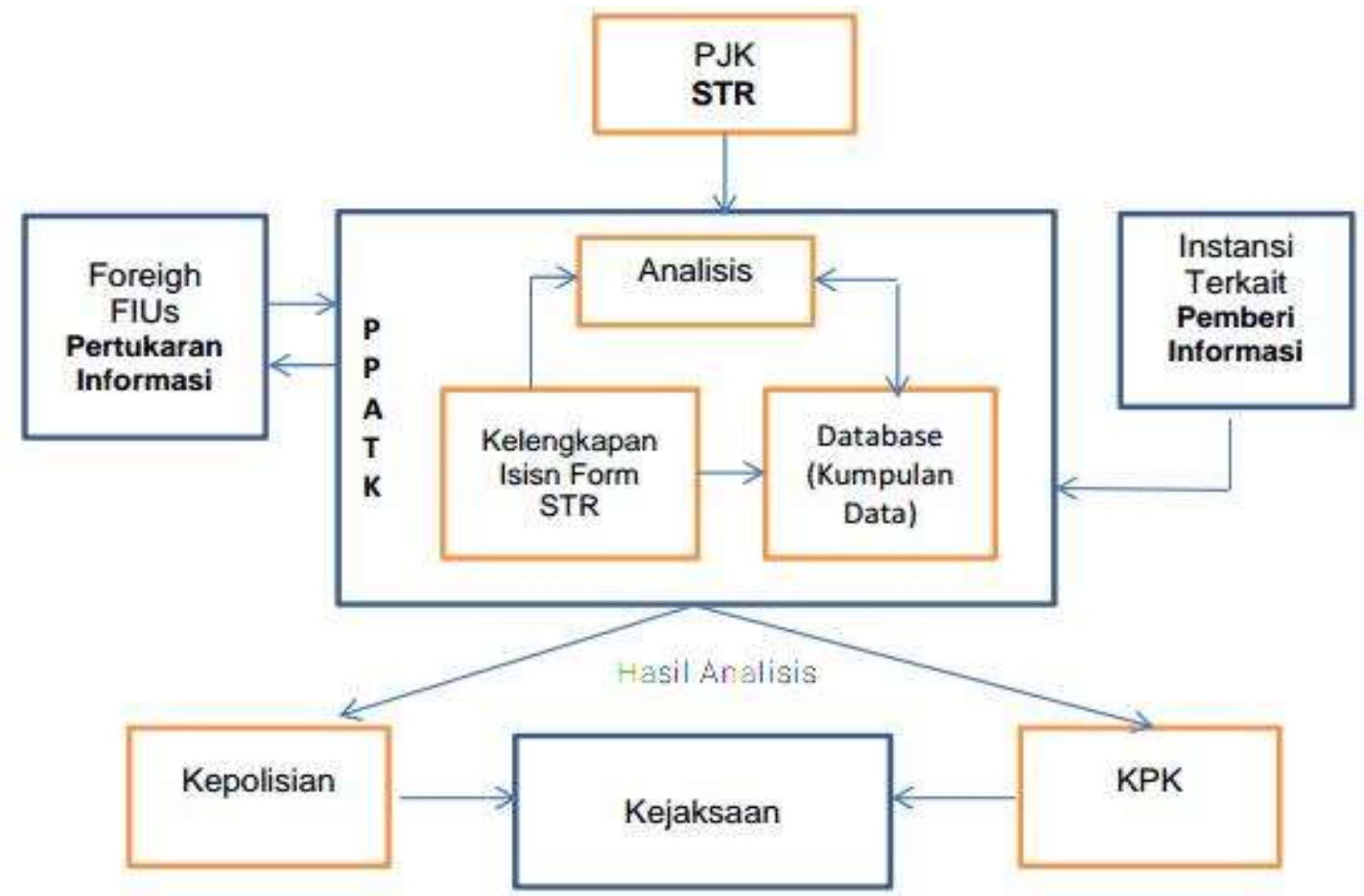

Figure 1. Role of PPATK

Source Chart: Yunus Husein

Analysis Results (HA) / Inquiry Inspection Results (HP) is a HA / HP compiled in order to follow up on an analysis / inspection request from law enforcement officials regarding the case being handled. ${ }^{22}$ The results of the examination are the final assessment of the entire process of problem identification, analysis and evaluation of suspicious financial transactions conducted independently, objectively and professionally which are submitted to the investigator. ${ }^{23}$

In Article 64 of Law Number 8 of 2010 concerning Prevention and Eradication of Money Laundering Crimes related to the analysis carried out by PPATK to be submitted to investigators, namely:

a. PPATK checks on Suspicious Financial Transactions related to indications of money laundering or other criminal acts.

b. In the event that an indication of a crime of money laundering or other criminal acts is found, the PPATK submits the Audit Result to the investigator for investigation.

c. In carrying out investigations as investigators coordinate with PPATK.

\footnotetext{
${ }^{21}$ Juni Sjafrien Jahja, Melawan Money Laundering: Mengenal, Mencegah, dan Memberantas Tindak Pidana Pencucian Uang, Cetakan II, Visi Media, Jakarta, 2014, p. 71-72

22 Refleksi Akhir Tahun 2017, Pusat Pelaporan Dan Analisis Transaksi Keuangan, http://www.ppatk.go.id/backend/assets/uploads/20171219165527.pdf.

${ }^{23}$ Muhammad Yunus, et al, Op.Cit, p. 470
} 
What is meant by examination in 64 paragraph 1 is the process of identifying problems, analyzing, and evaluating Suspicious Financial Transactions conducted independently, objectively, and professionally to assess allegations of criminal acts as contained in Article 1 number 7.

Examinations carried out by PPATK regarding suspicious transactions submitted by the reporting party to the PPATK can also come from documents received or obtained by PPATK. The financial transaction is suspicious, which is examined by the PPATK, not only suspicious financial transactions related to criminal acts of money laundering but also other criminal acts, namely corruption, funding of terrorism, narcotics, and others.

Based on the findings of indications of money laundering or other criminal acts, the PPATK submits the Audit Results to investigators for investigation. In this case the investigator coordinates with PPATK. ${ }^{24}$ So if the process of criminal offense is underway investigators must work together with PPATK to trace the assets of the suspect or the defendant on condition that they must submit an application to the PPATK first. So that PPATK can ask financial services to temporarily terminate all or part of the transaction.

According to R Wiyono what is meant by "temporary termination of all or part of the transaction" is not implementing what is known or suspected to be the result of a criminal act. ${ }^{25}$ This means that in terminating the transaction PPATK will analyze the money owned by assets or wealth (money / funds) of the suspect or defendant based on data from financial services, so that if it is found that the money is problematic the PPATK will inform the investigator for an investigation.

However, according to Wiyono, the results of the examination are not evidence and are prohibited from being used as "evidence." Because the evidence is valid in Article 73 of Act Number 8 of 2010 concerning Prevention and Eradication of Money Laundering Crimes, namely:

a. Evidence as referred to in the Criminal Procedure Code; and / or;

b. Other evidence in the form of information that is said, sent, received, or stored electronically with optical devices or similar optical devices and documents.

Even in other crimes, if law enforcement officials do not dismiss documents or information in order to carry out their duties, the documents or information must be kept secret to anyone. As stipulated in Article 11 of Act Number 8 of 2010 concerning Prevention and Eradication of Money Laundering Crimes, namely:

(1) PPATK officials or employees, investigators, public prosecutors, judges, and everyone who obtains documents or information in order to carry out their duties according to this law must keep the documents or information confidential, except to fulfill obligations under this law.

(2) Anyone who violates the provisions referred to in paragraph (1) shall be punished with a maximum imprisonment of 4 (four) years.

(3) Provisions as referred to in paragraph (1) do not apply to officials or employees of PPATK, investigators, public prosecutors and judges if carried out in order to fulfill obligations in accordance with the provisions of the legislation.

The word "everyone" refers to the subject of law in the narrow sense that people carry out their duties according to the law that are obliged to keep the Documents or information confidential and anyone who violates will be punished by imprisonment for a maximum of 4 (four) years. run in accordance with the provisions of the legislation. Then it is excluded for officials or employees of PPATK, investigators, public prosecutors and judges if carried out in order to fulfill obligations in accordance with the provisions of the legislation.

The question is whether to make evidence the results of the PPATK analysis can be excluded. According to the author, it can be excluded by referring to Article 11 paragraph 3, because the Article gives a mandate to officials or employees of PPATK, investigators, public prosecutors and judges in fulfilling obligations in accordance with the provisions of legislation. So that R. Wiyono's statement is wrong, because only based on the provisions of Article 11 paragraph 1.

This is also supported by Article 73 letter a, namely evidence as referred to in the Criminal Procedure Code which consists of witness testimony of expert testimony, letters, instructions and statements of the

\footnotetext{
${ }^{24}$ Ibid, p. 147

${ }^{25}$ R. Wiyono, Pembahasan Undang-Undang Pencegahan dan Pemberantasan TindaK Pidana Pencucian Uang, Mold I, Sinar Grafika, Jakarta, 2014, p. 188
} 
defendant. Therefore, the PPATK Examination results enter evidence on the letter because the investigation starts from investigation until the trial is HA (Analysis Result).

Some prominent case handling related to HA/HP (Examination / Results of Analysis) Inquiry conducted by PPATK in 2017 include: $^{26}$

a. The Role of PPATK in Disclosure of Fraud of First Travel Umrah Congregations.

"The Umrah pilgrimage fraud case carried out by the First Travel travel agency in August became one of the most serious cases that emerged throughout 2017. Allegedly First Travel committed fraud and embezzlement of 64,685 pilgrims who were going to Umrah. The total loss of pilgrims is estimated at Rp. 924,995,500,000.00. Public eyes highlighted the two figures of First Travel owners and their families, namely Andika Surachman, Anniesa Hasibuan, and Kiki Hasibuan. The mode is to promise prospective pilgrims to go on low-cost umrah with a specified time target. Until the deadline, prospective pilgrims did not accept the scheduled departure of a number of victims claiming to be asked to submit additional fees so that they could leave. and produce 2 Analysis Results (HA). The results of the PPATK analysis support the investigators in finding the flow of funds related to the use of pilgrim funds and finding ownership of assets at home and abroad on behalf of suspects who are expected to be used as a substitute for the victims' losses. The suspect is alleged to have violated Article 378 of the Criminal Code and or Article 372 of the Criminal Code in conjunction with Article 55 of the Criminal Code, Article 3 and Article 5 of Law Number 8 of 2010 concerning Money Laundering. The position of the case is still in the Police Criminal Investigation Unit. “27

The case, the role of PPATK in the Prevention of Money Laundering in the Funds Transfer Report from / to Foreign Affairs (LTKL) related to First Travel and produced 2 Results of Analysis (HA). The results of the PPATK analysis support the investigators in finding the flow of funds related to the use of pilgrim funds and finding ownership of assets at home and abroad on behalf of suspects who are expected to be used as a substitute for the victims' losses. This addresses the role of the PPATK in the prevention of ongoing criminal offenses, namely criminal acts threatened by Article 378 of the Criminal Code and or Article 372 of the Criminal Code in conjunction with Article 55 of the Criminal Code, Article 3 and Article 5 of Law Number 8 of 2010 concerning Money Laundering. The position of the case is still at the stage in the National Police Bareskrim.

b. Contribution of PPATK in Disclosure of Electronic KTP Corruption Cases

"PPATK received 93 LTKM and 151 LTKL in the alleged corruption of the Electronic KTP project. Since 2014 until now, PPATK has produced 11 HA which have been submitted to related Investigators. PPATK works to use the concept of follow the money in the account flow of funds transactions that allegedly found the flow of funds allegedly related to the flow of E-KTP funds starting from the process of payment of funds related to project work, to find patterns of transactions used by suspects and related parties in hiding and disguising funds. Transaction tracking is carried out by coordinating with the Corruption Eradication Commission (KPK) and cooperating with other countries' financial intelligence agencies on suspicion of the flow of funds from parties flowing through the country. Tracking the flow of funds through the concept of follow the money upstream transactions in the form of disbursement of project payment funds to tracing the flow of individual and corporate transaction funds, both domestic transactions and foreign transactions allegedly flowing through the project's funds. Estimated state losses of Rp 2.3 trillion. Regarding the flow of funds, it is expected to be able to disclose assets that are thought to have originated from the proceeds of corruption, both at home and abroad. The position of the case itself is currently in the trial stage."

In the case process, the PPATK E-KTP uses the concept of follow the money in the party's account fund flow transaction which is allegedly related to the flow of E-KTP funds starting from the payment process and project work, to finding patterns of transactions used by suspects and related parties fund. Search using this concept will certainly reveal all involved in it, because it will start from funding to implementation. In the theory of criminal law this kind of concept applies causalite theory which generally consists of 3 (three) theories namely Conditio Sine Qua Theory Non, Individualizing, and Generalizing to find the perpetrators and criminal liability of each actor who has the mens rea and actus

\footnotetext{
${ }^{26}$ Refleksi Akhir Tahun 2017, Op.Cit,.

${ }^{27}$ Refleksi Akhir Tahun 2017, Op.Cit,.
} 
reus errors. So that from the report PPATK found 11 Results of Analysis then submitted to investigators for investigation.

According to Yunus Husein, the anti-money laundering, disclosure of criminal acts and perpetrators are carried out through tracking financial transactions or flow of funds. Searching for financial transactions or flow of funds is the easiest way to ensure the occurrence of crime, find the culprit, and the place where the results of crime are hidden or disguised. This approach is inseparable from thinking and the belief that the results of crime are Life-blood of the crime, meaning that the results of crime are "blood" that supports crime itself as well as the weakest point of the crime chain. ${ }^{28}$

c. PPATK in the Disclosure of AW 101 Helicopter Procurement Corruption Cases

"During the period of December 2016 until June 2017, PPATK has made 4 HA related cases of Corruption Crime Procurement of AW 101 Helicopters based on 30 LTKMs and 51 LTKLs entered. Tracking account transactions and fund flows based on the PPATK database and the International Fund Transfer Instruction Report (IFTI) application found a transaction flow related to the purchase of the AW 101 Helicopter to partner companies that were greater than the purchase price of helicopters to overseas manufacturers. This procurement was indicated by corruption in the mark-up of helicopter purchases which were later indicated to flow to members of the TNI, Private Sector and other parties. The position of the case itself was in the stage of a joint investigation between the Indonesian Air Force KPK and POM. Coordination between institutions namely KPK, Puspom TNI, and PPATK was carried out intensively in the settlement of the case. Regarding the tracing of the fund flow that has been done, it is hoped that the funds can be saved from the criminal acts of corruption that can be returned to the State Treasury."

Interesting in corruption cases relating to the procurement of goods and services is the cooperation of agencies in the law enforcement process, so that the role of tracking account transactions and cash flow based on the PPATK database and the International Fund Transfer Instruction Report (IFTI) application found a transaction flow related to the purchase of helicopters AW 101 to a partner company that is greater than the purchase price of a helicopter to an overseas manufacturer. Therefore, the PPATK submitted to investigators to conduct an investigation.

Based on a number of prominent case handling related to Examination / Results Analysis that indicated suspicious transactions, cash transactions over five hundred million rupiahs, or transfers from and or abroad, then proceed to the process of proving money laundering by investigators, both as Police Investigators, Prosecutors and the Corruption Eradication Commission (KPK), the role of the PPATK is very decisive in the process of verifying whether the money is the result of other crimes or not through an approach that follows the money by exploring the origin of the money.

\section{Conclusion}

PPATK's Duties and Authorities in Law 8 of 2010 concerning Prevention and Eradication of Money Laundering Crimes. The aim of the PPATK is to Prevent and Eradicate Money Laundering Crimes, thus giving birth to an authority, namely 1). Collect, conclude, collect, analyze, evaluate information obtained from financial service providers, make guidelines on procedures for reporting suspicious financial transactions, 2). Provide advice and assistance to other authorized agencies regarding information obtained in accordance with the provisions of the Act on Money Laundering, 3). Provide recommendations to the government regarding the prevention and eradication of criminal acts of money laundering, 4). Report the results of analysis of financial transactions that indicate criminal acts of money laundering to the police for the purposes of investigation and prosecution for the purposes of prosecution and supervision, and 5). Make and submit reports on the analysis of financial transactions and other activities periodically to the President, Parliament, and institutions authorized to supervise Financial Service Providers (PJK).

Role of PPATK in Proving Money Laundering Crime, namely PPATK in eradicating criminal acts of money laundering if it finds any indication of suspicious transactions, cash transactions over five hundred million rupiahs, or transfers from and or abroad PPATK submits the results of examination to investigators to do investigation. In this case the PPATK only conducts the final assessment of the entire process of problem identification, analysis, evaluation of suspicious financial transactions conducted independently,

${ }^{28}$ Khairul, Mahmul Siregar, Marlina, Op.Cit, p. 34 
objectively and professionally. However, the role of PPATK is very decisive in the process of identifying money from original crimes as evidence for investigators in proving the crime of money laundering.

\section{References}

\section{Books}

[1] Amiruddin \& ZainalAsikin. 2006. Pengantar Metode Penelitian Hukum. Print VII. PT Raja Grafindo Persada, Jakarta.

[2] Juni Sjafrien Jahja. 2014. Melawan Money Laundering: Mengenal, Mencegah, dan Memberantas Tindak Pidana Pencucian Uang. Mold II. Visi Media, Jakarta.

[3] Herri Swantoro. 2017. Harmonisasi Keadilan dan Kepastian Dalam Peninjauan Kembali. Mold I. Kencana, Jakarta.

[4] Muhammad Yusuf. 2016. Kapita Selekta TPPU: Kumpulan Pembahasan Mengenai Isu-Isu Terkini. Mold II. Pusat Pelaporan dan Analisis Transaksi Keuangan (PPATK), Jakarta.

[5] Mukti Fazar ND \& Yulianto Achmad. 2017. Dualisme Penelitian Hukum Normatif dan Empiris. Print IV. Pustaka Pelajar, Jakarta.

[6] Peter Mahmud Marzuki. 2016. Penelitian Hukum. Print XII. Kencana, Jakarta.

[7] R. Wiyono. 2014. Pembahasan Undang-Undang Pencegahan dan Pemberantasan Tindak Pidana Pencucian Uang. Mold I. Sinar Grafika, Jakarta.

[8] Yenti Garnasih. 2016. Penegakan Hukum Anti Pencucian Uang dan Permasalahannya di Indonesia. Mold III. Rajagrafindo Persada, Jakarta.

\section{Journals}

[1] Amelia Fransisca Wattie, Peran PPATK Dalam Penyidikan Tindak Pidana Pencucian Uang, (Jurnal), Lex Crimen Vol. IV/No. 3/May/2015.

[2] Christian Sondakh, Kewenangan PPATK dalam Menanggulangi Tindak Pidana Pencucian Uang Menurut Undang-Undang No. 8 Tahun 2010, (Jurnal), Lex Crimen Vol. IV/No. 8/Oct/2015152.

[3] Ilman Mujaddid, Kebijakan Hukum Pidana Dalam Pemberantasan Tindak Pidana Pencucian Uang, (Jurna), Jurnal IUS, Vol IV, Number 1, April 2016.

[4] Johari, Tugas Dan Wewenang Pusat Pelaporan dan Analisis Transaksi Keuangan (PPATK) Dalam Pemberantasan Tindak Pidana Pencucian Uang, (Jurnal) Fiat Justisia Jurnal Ilmu Hukum Volume 5 No. 3, September -December 2011.

[5] Khairul, Mahmul Siregar, Marlina, Kewenangan PPATK Dalam Pencegahan Dan Pemberantasan Tindak Pidana Pencucian Uang, (Jurnal) Mercatoria Vol. 4 No. 1 of 2011.

[6] Rido Tri Sandi Rambe, Peranan Pusat Pelaporan Analisis Transaksi Keuangan (PPATK) Dalam Mencegah Tindak Pidana Pencucian Uang Dengan Modus Private Banking Berdasarkan UndangUndang Nomor 8 Tahun 2010 Tentang Pencegahan Dan Pemberantasan Tindak Pidana Pencucian Uang, (Jurnal), JOM Fakultas Hukum Volume III Number 1 February 2016.

\section{Regulations}

[1] Indonesia, Law Number 30 of 2014 concerning Government Administration.

[2] Indonesia, Law Number 8 of 2010 concerning Prevention and Eradication of Money Laundering Crimes. 